DOI 10.14746/ssp.2020.1.1

Krzysztof ŻĘGOTA

Uniwersytet Warmińsko-Mazurski w Olsztynie

ORCID: 0000-0003-1925-197X

\title{
Polsko-rosyjska współpraca transgraniczna i relacje polsko-rosyjskie w programach wybranych partii politycznych i deklaracjach ich przedstawicieli w województwie warmińsko-mazurskim. Zarys analizy wyników badań terenowych ${ }^{1}$
}

Streszczenie: Celem artykułu jest analiza jakościowa wyników wywiadów, przeprowadzonych z przedstawicielami ugrupowań politycznych z województwa warmińsko-mazurskiego pod kątem miejsca polsko-rosyjskiej współpracy transgranicznej oraz relacji polsko-rosyjskich w programach partii politycznych. Przeprowadzone badanie udowodniło, iż przedstawiciele wszystkich partii politycznych, uwzględnionych w wywiadzie, dostrzegają istotne miejsce relacji polsko-rosyjskich tak w programach swoich partii, jak i w życiu politycznym województwa warmińsko-mazurskiego. Przedstawiciele partii podkreślają znaczenie polsko-rosyjskiej współpracy transgranicznej dla funkcjonowania regionalnej sceny politycznej. Większość respondentów ocenia, iż stosunek mieszkańców regionu do Rosji i idei współpracy transgranicznej jest pozytywny.

Słowa kluczowe: polsko-rosyjska współpraca transgraniczna, relacje polsko-rosyjskie, partie polityczne, programy partyjne

\section{Wstęp}

$\mathbf{Z}$ naczącym komponentem dyskursu publicznego są programy polityczne, wyrażane przez poszczególne partie i ugrupowania politycz-

1 Publikacja stanowi kontynuację i rozwinięcie artykułu Relacje z Federacją Rosyjska w programach wybranych polskich ugrupowań politycznych - zarys analizy ilościowej i jakościowej, opublikowanego w nr 4(63)/2018 czasopisma „Myśl Ekonomiczna i Polityczna". W niniejszym artykule uwzględniono podobny problem badawczy, to jest miejsce relacji z Federacją Rosyjską w programach partii politycznych. Zarazem, istotnym novum niniejszego artykułu jest oparcie analizy jakościowej na wynikach badań terenowych (nie zaś dokumentów partyjnych) oraz przyjęcie optyki regionalnej, odnoszącej się z jednej strony do transgranicznego wymiaru relacji polsko-rosyjskich, a z drugiej do ugrupowań politycznych i ich przedstawicieli, działających w województwie warmińsko-mazurskim. Por. Żęgota, 2018b, s. 157-183. 
ne. Jak zauważają badacze, rzeczywistość polityczna generuje znaczącą ilość materiału badawczego, dotyczącego poglądów i programów partii politycznych, który jest potencjalnym przedmiotem badań politologicznych, i który - bezpośrednio i pośrednio - może stanowić źródło informacji na temat programów partii politycznych. W. Woźniak podkreśla, że takim źródłem mogą być nie tylko sformalizowane dokumenty programowe, przygotowywane najczęściej na potrzeby kampanii wyborczych czy konwencji programowych, ale i źródła o charakterze pośrednim: ,zapisy debat toczonych w publicznych instytucjach (transkrypcje dyskusji w parlamentach, radach miast, komisjach różnego szczebla etc.), a także zapisy medialnych wystąpień polityków [...]" (Woźniak, 2017, s. 41-42).

Zarazem badacze dopuszczają poszerzenie katalogu źródeł programów politycznych poszczególnych ugrupowań politycznych o praktykę polityczną partii i ich przedstawicieli oraz wywiady ${ }^{2}$. W. Woźniak podkreśla, iż $\mathrm{w}$ analizie programów politycznych partii wykorzystuje się również zapisy debat w mediach elektronicznych oraz źródła wywołane: zapisy wywiadów indywidualnych i grupowych (Woźniak, 2017, s. 46). Z kolei A. Indraszczyk wśród źródeł programów politycznych partii wymienia m.in. enuncjacje polityczne, artykuły polityczne oraz wywiady polityczne (Indraszczyk, 2008, s. 32). Powyższe argumenty wykazują, iż w pełni uzasadnione jest poszerzenie katalogu źródeł programów partii i ugrupowań politycznych również o wyniki wywiadów, przeprowadzanych z przedstawicielami poszczególnych ugrupowań.

Usystematyzowania wymaga również warsztat pojęciowy, dotyczący programów politycznych. Program polityczny jest w piśmiennictwie definiowany jako spójny zbiór zadań i planów partii i ugrupowań politycznych, którego nadrzędnym celem jest przekonanie wyborców, a następnie zdobycie i utrzymanie władzy (Antoszewski, Herbut, 2004, s. 349). Pojęciem zbliżonym jest pojęcie programu wyborczego, które jest interpretowane jako zbiór postulatów i planów partii politycznych, przygotowywanych na potrzeby kampanii wyborczej. Przyjmuje on zazwyczaj postać sformalizowanego dokumentu, uchwalanego przez kompetentne organy partyjne, którego celem jest artykułowanie postulatów partii przewidzianych do realizacji w przypadku dojścia do władzy (Tyrała, 2018, s. 62).

2 Jako przykład można podać aktywność legislacyjną poszczególnych partii politycznych pod kątem legalizacji związków partnerskich, która była przedmiotem analizy programów politycznych przeprowadzonych przez K. Zawadzką w artykule Zwiazki partnerskie mniejszości seksualnych w programach polskich partii politycznych. Zob. Zawadzka, 2016, s. 49-57. 
Badacze podkreślają również rolę i znaczenie programów politycznych w kształtowaniu dyskursu publicznego. Zgodnie ze spostrzeżeniami P. Maira, współczesna demokracja liberalna cechuje się oddalaniem się partii politycznych od obywateli w ten sposób, iż programy partii w coraz mniejszym stopniu odpowiadają na społeczne oczekiwania i coraz słabiej wyrażają poglądy wyborców (Mair, 2017, s. 361-367; Tyrała, 2018, s. 63). J. Raciborski zauważa, że w polskiej rzeczywistości politycznej partie propagują swoje programy nie po to by je realizować, lecz w pierwszej kolejności po to, by wygrać wybory (Raciborski, 2003, s. 208).

Zarazem programy stanowią nadal podstawowe źródło wiedzy na temat zamierzeń i planów partii politycznych. W ocenie H. Kitschelta, partie polityczne stanowią swoiste wspólnoty idei, które pozwalają wyborcom utożsamiać się z nimi i dokonywać świadomych wyborów politycznych (Kitschelt, 1999; Tyrała, 2018, s. 63). I. Budge stwierdza z kolei, iż programy polityczne są kluczowymi dokumentami, pozwalającymi odtworzyć całościową wizję ładu społecznego i gospodarczego, proponowanego przez daną partię. W tym kontekście programy polityczne należy traktować jako swoisty pomost między partiami a ich elektoratem oraz zasadniczy czynnik dyferencjacji ofert poszczególnych ugrupowań (Budge, 1994; Budge, Klingemann, Volkens, Bara, McDonald, 2006, s. XVI; Woźniak, 2017, s. 42). Natomiast T. Rapley podkreśla rolę dokumentacyjną programów politycznych, odzwierciedlających zmiany w dyskursie publicznym, zarówno pod względem jego intensywności, jak i tematyki (Rapley, 2010, s. 37-48).

\section{Metodologia badania}

Wpływ programów ugrupowań politycznych na kształtowanie dyskursu publicznego skłonił autora do podjęcia próby oceny roli i znaczenia programów politycznych poszczególnych ugrupowań z punktu widzenia miejsca relacji z Federacją Rosyjską. Tematyka ta stanowi, od co najmniej kilkunastu lat, istotny element polskiej polityki zagranicznej. Toteż, tym bardziej zasadne wydaje się poddanie analizie miejsca tego zagadnienia w programach partii politycznych. Zarazem postanowiono odnieść się do dwu zasadniczych dylematów badawczych, z którymi autor miał do czynienia w trakcie analizy ilościowej i jakościowej dokumentów programowych partii, przeprowadzonej w ramach prac przygotowawczych 
do niniejszej publikacji ${ }^{3}$. Po pierwsze, w programach części ugrupowań tematyka relacji polsko-rosyjskich była nieobecna lub stanowiła element marginalny i przedstawiany w sposób powierzchowny. Po drugie zaś, w programach i pragmatyce działania szeregu partii dostrzeżono istotne różnice pomiędzy optyką władz centralnych poszczególnych ugrupowań, a deklaracjami przedstawicieli partii w tzw. „terenie”. Problem ten dotyczy w szczególności województwa warmińsko-mazurskiego, którego przygraniczne położenie determinuje występowanie pewnego dysonansu między deklaracjami regionalnych działaczy a zapisami dokumentów programowych partii.

Wobec tego, autor postanowił skonfrontować zapisy dokumentów partyjnych z deklaracjami ich przedstawicieli w województwie warmińsko-mazurskim, uzyskanych poprzez przeprowadzenie wywiadów. Celem niniejszego artykułu jest - w konsekwencji - analiza jakościowa wyników wywiadów, przeprowadzonych z poszczególnymi przedstawicielami ugrupowań politycznych z województwa warmińsko-mazurskiego oraz konfrontacja tych wyników z zapisami dokumentów programowych. Regionalny $-w$ gruncie rzeczy - charakter badania zdeterminował tematykę wywiadów, którą była polsko-rosyjska współpraca transgraniczna w kontekście relacji polsko-rosyjskich.

Warto podkreślić, iż problematyka rosyjska pojawia się w programach partii politycznych głównie w trzech zasadniczych obszarach tematycznych: uwarunkowania polskiej polityki zagranicznej i bezpieczeństwa, polityka europejska i wyzwania stojące przed integracją euroatlantycką oraz relacje handlowe Polski ze Wschodem (Żęgota, 2018b, s. 161). Wobec tego, zagadnienie to zostało $\mathrm{w}$ wywiadach potraktowane jako element szerszego kontekstu postulatów i enuncjacji programowych, występujących w programach poszczególnych partii, a odnoszących się do relacji z Rosją.

Postawiono następujące pytania badawcze: jakie miejsce w programach partii politycznych zajmują relacje z Rosją? Jak relacje polsko-rosyjskie mogą wpływać na dyferencjację sceny politycznej województwa warmińsko-mazurskiego? W jaki sposób tematyka relacji polsko-rosyjskich w wymiarze regionalnym może implikować dyskurs publiczny?

Zasadniczym problemem metodologicznym było zastosowanie adekwatnych do przedmiotu badania metod i technik badawczych. Jedną $\mathrm{z}$ metod badań politologicznych - zastosowaną w niniejszym badaniu

${ }^{3}$ Rezultatem prac przygotowawczych był wspomniany już artykuł Relacje $z \mathrm{Fe}$ deracją Rosyjską... Zob. Żęgota, 2018b, s. 157-183. 
- są ujęcia jakościowe. Odnoszą się one do badania zjawisk masowych, charakterystycznych dla rzeczywistości społeczno-politycznej, do których należy zaliczyć również przynależność do określonych nurtów ideologicznych, doktryn i programów politycznych (Chodubski, 2004, s. 120). W toku realizacji badania przeprowadzono jakościową analizę materiałów źródłowych, jakimi były kwestionariusze wywiadów, głównie pod kątem skali i charakteru występowania tematyki relacji z Rosją w programach ugrupowań politycznych.

W badaniu zastosowano również analizę komparatystyczną. Metoda ta pozwala na porównywanie siły i częstotliwości występowania zjawisk i procesów, co prowadzi do ustalenia podobieństw i różnic między nimi (Chodubski, 2004, s. 125). W badaniu dokonano porównania obecności problematyki rosyjskiej w programach partii politycznych oraz postulatów odnoszących się do relacji z Rosją, wynikających z deklaracji przedstawicieli partii, zawartych w kwestionariuszach wywiadów.

Badania terenowe zostały przeprowadzone w oparciu o technikę wywiadu, dla którego przygotowano kwestionariusz wywiadu ${ }^{4}$. Charakterystyka wywiadów jest związana z przeprowadzeniem rozmowy z respondentem, w trakcie której badacz nie tylko zadaje pytania, ale i może stymulować charakter odpowiedzi. Wywiady mogą przyjąć postać ustną lub pisemną, skategoryzowaną lub nieskategoryzowaną, jak również indywidualną lub zbiorową (Chodubski, 2004, s. 139-140). W ramach niniejszego badania przeprowadzono wywiady skategoryzowane, ustne, które zarazem przybrały formę indywidualną.

W kwestionariuszu wywiadu zawarto pytania, które zostały skupione w trzech grupach problemowych: 1) miejsce relacji z Rosją w programach ugrupowań politycznych; 2) relacje polsko-rosyjskie w wymiarze regionalnym i lokalnym; 3) prognoza rozwoju relacji polsko-rosyjskich w przyszłości. Pytania uwzględnione w kwestionariuszu dotyczyły następujących zagadnień szczegółowych:

- miejsce relacji z Rosją w programach partii;

- postulaty partii w odniesieniu do zmian tych relacji;

- ocena zawieszenia mechanizmu małego ruchu granicznego (MRG);

- wpływ zawieszenia MRG na rozwój społeczno-gospodarczy obszarów przygranicznych;

- ocena polityki sankcyjnej w relacjach Unii Europejskiej i Rosji;

${ }^{4}$ Warto podkreślić, iż pojęcia metody i techniki badawczej są nieostre, zaś w piśmiennictwie naukowym brak jest jednoznacznego rozdziału metod i technik badawczych. Zob. Bäcker i in., 2016, s. 66-67; por. Chodubski, 2004, s. 139-142. 
- ocena nastawienia mieszańców województwa warmińsko-mazurskiego do Rosjan i relacji z Rosją;

- miejsce relacji z Rosją w kampanii przed wyborami samorządowymi;

- miejsce relacji z Rosją w regionalnych i lokalnych mediach oraz dyskursie publicznym w regionie;

- ocena potencjału do powstania ruchu społecznego w województwie opowiadającego się za poprawą relacji z Rosją;

- ocena różnic w programie politycznym partii a aktywnością lokalnych polityków partii w województwie warmińsko-mazurskim;

- kwestia działań partii, które zamierza ona podjąć w odniesieniu do relacji z Rosją po dojściu do władzy (poprawić, pogorszyć, pozostawić na niezmienionym poziomie);

- ocena szans na sukces polityczny partii opowiadającej się otwarcie za polepszeniem relacji z Rosją ${ }^{5}$.

Zasadniczym wyzwaniem był również dobór partii politycznych, ich przedstawicieli oraz określenie cezury czasowej badania. Główną przesłanką była chęć uwzględnienia w badaniu partii politycznych posiadających swoich przedstawicieli w Sejmie i Senacie ${ }^{6}$. Zarazem, wobec konieczności zaprezentowania różnorodności poglądów, dotyczących relacji z Rosją, postanowiono poszerzyć katalog partii o niektóre ugrupowania pozaparlamentarne - kierowano się tu głównie faktem funkcjonowania i poziomem aktywności struktur danego ugrupowania w województwie warmińsko-mazurskim.

Kolejnym dylematem badawczym był dobór odpowiednich przedstawicieli poszczególnych ugrupowań politycznych, których odpowiedzi, z jednej strony, w sposób adekwatny reprezentowałyby programy i postulaty poszczególnych partii, a z drugiej, którzy posiadaliby wiedzę na temat problematyki relacji polsko-rosyjskich oraz polsko-rosyjskiej współpracy transgranicznej. Przyjęto założenie, zgodnie z którym - w przypadku posiadania przez dane ugrupowanie reprezentacji $\mathrm{w}$ polskim parlamencie - $\mathrm{w}$ badaniu weźmie udział poseł lub senator. W przypadku braku deputowanych w parlamencie uwzględniono moż-

5 Pełna treść kwestionariusza wywiadu znajduje się w zasobach autora.

${ }^{6}$ Oparto się na dokumencie ,Wykaz partii wpisanych do ewidencji partii politycznych (na podstawie prawomocnych postanowień w sprawach o wpis do ewidencji przekazanych Państwowej Komisji Wyborczej przez Sąd Okręgowy w Warszawie w trybie określonym art. 15 ustawy o partiach politycznych)", dostępnym na stronie internetowej Państwowej Komisji Wyborczej: http://pkw.gov.pl/322_Wykaz_partii_ politycznych, 22.11.2018. 
liwość reprezentowania partii przez przedstawiciela zarządu struktur regionalnych lub ogólnopolskich. W rezultacie, w badaniu uczestniczyło 10 przedstawicieli partii i ugrupowań politycznych: Iwona Arent (posłanka - Prawo i Sprawiedliwość), Bartosz Grucela (członek zarządu okręgu Olsztyn - Razem), Tomasz Jankowski (członek Rady Krajowej - Partia Zmiana ${ }^{7}$ ), Krzysztof Kacprzycki (przewodniczący okręgu Olsztyn - Sojusz Lewicy Demokratycznej $\left.{ }^{8}\right)$, Andrzej Maciejewski (poseł - Kukiz'15), Mirosław Pampuch (poseł - Nowoczesna), Urszula Pasławska (posłanka - Polskie Stronnictwo Ludowe), Jacek Protas (poseł - Platforma Obywatelska RP), Michał Wypij (prezes zarządu okręgowego w Olsztynie - Porozumienie) oraz Andrzej Wyrębek (prezes okręgu Elbląg - Wolność).

Badanie przeprowadzono pomiędzy marcem a listopadem 2018 r. Było to podyktowane, z jednej strony, dynamiką zmian na scenie politycznej województwa warmińsko-mazurskiego, a z drugiej, trwającą kampanią wyborczą przed wyborami samorządowymi. Warto przy tym uwypuklić zasadnicze determinanty relacji polsko-rosyjskich $\mathrm{w}$ omawianym okresie, które przecież znacząco wpływały na deklaracje respondentów. Pierwszym czynnikiem był konflikt na wschodzie Ukrainy, obserwowany na przestrzeni 2014 i 2015 r. oraz aneksja Krymu, co wywołało reakcję Unii Europejskiej, w tym Polski, w postaci sankcji gospodarczych i politycznych. W omawianym okresie relacje unijno-rosyjskie i polsko-rosyjskie uległy znaczącemu pogorszeniu, co wpływało również na opinie społeczności lokalnych polsko-rosyjskiego pogranicza. W sierpniu $2014 \mathrm{r}$. władze rosyjskie nałożyły na państwa członkowskie Unii Europejskiej embargo na import szeregu produktów rolno-spożywczych, co w znacznej mierze dotyczyło polskiego sektora przetwórstwa rolno-spożywczego (Rosińska-Bukowska, 2015).

Drugim zasadniczym czynnikiem implikującym relacje polsko-rosyjskie, w szczególności na poziomie regionalnym i lokalnym, było zawie-

${ }^{7}$ Należy zauważyć, iż z formalnego punktu widzenia Zmiana nie jest partią, gdyż wniosek o wpisanie do ewidencji partii politycznych został odrzucony. Zob. Aresztowany prokremlowski polityk rejestruje partię. Prokuratura stara się to zablokować, https:/www.tvn24.pl/wiadomosci-z-kraju,3/zmiana-aresztowany-prokremlowskipolityk-rejestruje-partie,675455.html, 14.01.2019. Zarazem, z punktu widzenia przeprowadzenia niniejszej analizy programów politycznych oraz ze względu na fakt używania słowa ,partia” w nazwie ugrupowania w oficjalnych dokumentach programowych, takie nazewnictwo zostało zastosowane przez autora w niniejszym artykule.

${ }^{8}$ K. Kacprzycki był członkiem Sojuszu Lewicy Demokratycznej do 7 listopada 2018 r. Zob. Koronowski, 2018. 
szenie, w lipcu 2016 r., małego ruchu granicznego na granicy polsko-rosyjskiej. Zgodnie z wyjaśnieniami przedstawicieli polskiego rządu, czasowe zawieszenie obowiązywania MRG (nie tylko na granicy z Rosją, ale i Ukrainą) było spowodowane kwestiami bezpieczeństwa, związanymi głównie z planowanymi wówczas w Polsce imprezami o charakterze międzynarodowym. Zawieszenie, a następnie nieprzywrócenie małego ruchu granicznego na granicy z Rosją wywołało krytyczne komentarze, szczególnie ze strony samorządowców i przedstawicieli społeczności lokalnych obszarów objętych mechanizmem po obu stronach granicy polsko-rosyjskiej (Żęgota, 2018a, s. 51). Zgodnie z opiniami większości ekspertów i obserwatorów polsko-rosyjskiej współpracy transgranicznej zawieszenie MRG na granicy polsko-rosyjskiej miało charakter przede wszystkim polityczny, co uzasadnia podjęcie badania w odniesieniu do opinii przedstawicieli poszczególnych ugrupowań politycznych. Problematyka poruszana $\mathrm{w}$ wywiadach miała charakter - w znacznej mierze - regionalny i lokalny, wszak jakość i charakter przeobrażeń polsko-rosyjskiej współpracy transgranicznej wpływa na rozwój społeczno-gospodarczy regionu.

\section{Programy ugrupowań politycznych a relacje z Rosją}

W pierwszej kolejności w badaniu uwzględniono ocenę roli i znaczenia relacji z Rosją w programach partii politycznych. Większość respondentów podkreśla, że w programach ich partii problematyka relacji z Rosją zajmuje ważne miejsce. W odpowiedziach dadzą się wyodrębnić trzy grupy opinii, dotyczących relacji z Rosją. Przedstawiciele pierwszej grupy partii, do której należałoby zaliczyć partię Wolność, Kukiz’15, Prawo i Sprawiedliwość oraz w pewnej mierze Porozumienie, postulują prowadzenie pragmatycznej polityki zagranicznej, nastawionej na realizację polskich interesów, zaś relacje dwustronne z Rosją powinny być wypadkową takiego pragmatycznego podejścia. Przedstawiciel partii Wolność deklaruje wprost: „Nie uwzględniamy w naszym programie relacji z Rosją. [...] Mamy za to postulat dobrej polityki zagranicznej. A dobra polityka zagraniczna to taka, która sprzyja naszym interesom handlowym, czy to w kontekście Rosji, czy innych państw [...]" (Kwestionariusz wywiadu - Andrzej Wyrębek, s. 1) $)^{9}$. Przedstawiciele Kukiz'15, PiS oraz

\footnotetext{
${ }^{9}$ Odpowiedzi udzielone przez Andrzeja Wyrębka (Wolność), podobnie jak kwe-
} 
Porozumienia postulują z kolei pragmatyzm i uwydatnianie zasady wzajemności w relacjach z Rosją.

Druga grupa partii - do której należy zaliczyć partię Razem, Platformę Obywatelską, Sojusz Lewicy Demokratycznej oraz Nowoczesną - to ugrupowania, których przedstawiciele deklarują przywiązywanie dużej wagi do relacji z Rosją, przy czym poszczególne elementy owych relacji uległy swoistej dyferencjacji. Przy dostrzeganiu coraz bardziej agresywnej polityki zagranicznej Rosji, w tym udziału w konflikcie na wschodzie Ukrainy i aneksji Krymu, postulują oni polepszenie relacji na poziomie transgranicznym. Zarazem przedstawiciele Platformy Obywatelskiej i Nowoczesnej postulują umiejscowienie relacji polsko-rosyjskich w szerszym kontekście relacji Unia Europejska-Rosja. Z kolei przedstawiciel SLD deklaruje, iż należy potępić agresję militarną Rosji, przy jednoczesnym dążeniu do współpracy przynajmniej w tych obszarach, których taka współpraca będzie obopólnie korzystna.

Trzecia grupa ugrupowań to partie, których przedstawiciele nie tylko podkreślają wagę i znaczenie relacji polsko-rosyjskich, ale i wskazują konkretne obszary, w których owe relacje powinny ulec polepszeniu. Przedstawiciel partii Zmiana postuluje ,zrównoważenie kontaktów Polski z państwami Zachodu poprzez rozwijanie również kontaktów ze Wschodem, w tym z Rosją tak, by Polska z kraju granicznego stała się 'bramą' między Wschodem i Zachodem. Szansą dla Polski jest w szczególności rozwój relacji handlowych [...]" (Kwestionariusz wywiadu - Tomasz Jankowski, s. 1). Z kolei U. Pasławska deklaruje, iż „Polskie Stronnictwo Ludowe jest jedyną partią, która podnosi temat wznowienia relacji handlowych z Rosją. [...] W Parlamencie Europejskim nasi parlamentarzyści wystąpili z inicjatywą, której celem było zniesienie sankcji gospodarczych wobec Rosji [...]" przy jednoczesnym utrzymaniu sankcji politycznych (Kwestionariusz wywiadu - Urszula Pasławska, s. 1).

Podobne rozróżnienie można wprowadzić, jeśli chodzi o postulowane zmiany w zakresie relacji z Rosją. Przedstawiciele Kukiz'15, Razem oraz Porozumienia podkreślają, że zmiany relacji są zależne od zbyt wielu czynników, by móc jednoznacznie odpowiedzieć czy należy je poprawić, czy też pozostawić na niezmiennym poziomie. Przedstawiciel partii Razem postuluje polepszenie współpracy społecznej, przy zachowaniu niezmiennego stanu relacji politycznych, natomiast respondent z par-

stionariusze z odpowiedziami pozostałych respondentów, znajdują się w zasobach autora. 
tii Porozumienie podkreśla, iż nie należy bez powodu antagonizować stosunków z Rosją. Przedstawiciele PO, PiS, SLD, PSL i Nowoczesnej uwzględniają możliwość poprawy relacji, lecz pod pewnymi warunkami. PO i Nowoczesna, w deklaracjach ich przedstawicieli, postulują rozwijanie współpracy społecznej, przy jednoczesnym zachowaniu asertywności na poziomie relacji politycznych. Przedstawicielka PiS podkreśla, iż poprawa relacji z Rosją jest potrzebna i możliwa, ale jedynie w przypadku szanowania przez Rosję prawa międzynarodowego. Jedynie przedstawiciele Wolności i Zmiany w sposób wyraźny postulują polepszenie relacji z Rosją, przy czym partia Wolność opowiada się gównie za poprawą relacji gospodarczych, w tym tych związanych z handlem surowcami, zaś Zmiana podkreśla brak zagrożenia politycznego i militarnego ze strony Rosji, czemu miałoby również pomóc postulowane przez to ugrupowanie wystąpienie Polski z NATO.

Kolejną kwestią była ocena respondentów, dotycząca zawieszenia mechanizmu małego ruchu granicznego (MRG) na granicy polsko-rosyjskiej oraz jego wpływu na rozwój gospodarczy i społeczny obszarów przygranicznych. Większość respondentów krytycznie wypowiedziała się na temat zawieszenia MRG i domaga się jego przywrócenia. Najbardziej stanowczo wypowiada się na ten temat przedstawiciel partii Wolność, który nazywa tę decyzję skandalem, podkreślając zarazem wynikające $\mathrm{z}$ tego straty gospodarcze województwa. Przedstawiciele PO i Nowoczesnej podkreślają, iż jedną z pierwszych decyzji po ewentualnym objęciu władzy przez ich ugrupowania powinno być przywrócenie MRG. Poseł J. Protas (PO) podważa argumenty za zawieszeniem ruchu, związane z kwestiami bezpieczeństwa, stwierdzając m.in., iż „Wszyscy doskonale wiemy, że jak ktoś chce prowadzić działalność szpiegowską, to nie na podstawie dokumentu MRG" (Kwestionariusz wywiadu - Jacek Protas, s. 2). Przedstawicielka PSL podkreśla wymiar gospodarczy zawieszenia MRG i realne straty przedsiębiorców, odnotowywane w powiatach przygranicznych.

Zarazem przedstawiciele PiS, Kukiz'15 i Porozumienia w większym bądź mniejszym stopniu wypowiadają się ze zrozumieniem wobec decyzji o zawieszeniu małego ruchu granicznego. Przedstawiciel $\mathrm{Ku}-$ kiz'15 zauważa spadek ruchu osobowego na granicy polsko-rosyjskiej, ale zarazem dostrzega, iż sama konstrukcja MRG posiadała wiele wad. Jednocześnie wyraża zrozumienie dla argumentów za utrzymaniem zawieszenia ruchu, związanych z kwestiami bezpieczeństwa. Przedstawiciel Porozumienia również wyraża zaufanie do decyzji ministra spraw 
wewnętrznych i administracji, dotyczącej zawieszenia MRG, podkreślając, iż kwestie - ze względów bezpieczeństwa - objęte są pewnym embargiem informacyjnym. Posłanka PiS, I. Arent podkreśla natomiast, iż „Decyzja o zawieszeniu stosowania MRG była podyktowana kwestiami bezpieczeństwa i powinna być oceniana z tej perspektywy" (Kwestionariusz wywiadu - Iwona Arent, s. 1), dodając, iż meldunki służb wywiadowczych podkreślały zmilitaryzowanie obwodu kaliningradzkiego. Zarazem przedstawicielka PiS zaznacza, iż MRG nie był wcale decydującym czynnikiem rozwoju społeczno-gospodarczego obszarów przygranicznych. Jego przywrócenie - w opinii posłanki - może nastąpić po zmianie polityki władz rosyjskich.

Zagadnieniem determinującym, w pewnym stopniu, programy partii politycznych w zakresie postulowanych relacji z Rosją, był również stosunek do sankcji między Unią Europejską a Federacją Rosyjską, wprowadzonych po aneksji Krymu przez Rosję w 2014 r. Postulat utrzymania sankcji, przynajmniej w aktualnie obserwowanych warunkach, głosi większość partii. Przedstawicielka Prawa i Sprawiedliwości podkreśla, że sankcje są rezultatem agresywnej polityki Rosji i, tak długo, jak długo się ona nie zmieni, sankcje powinny być utrzymane. Poza tym, polityka sankcyjna Unii Europejskiej nie wpływa wprost w sposób negatywny na gospodarkę regionu. Podobne argumenty podnosi przedstawiciel $\mathrm{Ku}-$ kiz’15, który zauważa, że i przed sankcjami polskie podmioty nie były zbyt obecne na rynku obwodu kaliningradzkiego FR. Z kolei dla przedstawiciela Nowoczesnej argumentem za utrzymaniem sankcji jest zarówno polityka międzynarodowa Federacji Rosyjskiej, jak i szeroko pojęta solidarność europejska.

Nieco odmienne stanowisko prezentują przedstawiciele Platformy Obywatelskiej oraz Porozumienia. Poseł J. Protas (PO) podkreśla m.in., że relacje z Rosją wymagają rozwagi. Jakkolwiek, polityka sankcyjna UE jest jak najbardziej uzasadniona i celowa, to wszędzie tam, gdzie działania polskie nie burzyłyby wspólnej polityki UE wobec Rosji - należy ze wschodnim sąsiadem współpracować. Podobnie uważa przedstawiciel Porozumienia, M. Wypij, który podkreśla, iż utrzymanie sankcji wobec Rosji wynika z lojalności wobec naszych sojuszników z UE. Zarazem twierdzi, iż ,jeśli chodzi o relacje na poziomie regionalnym, powinniśmy robić to, co jest możliwe do zrobienia. Jeżeli możliwe są relacje gospodarcze, to w żaden sposób nie powinniśmy ich zawieszać. Jeżeli mamy możliwości współpracy na poziomie transgranicznym, powinniśmy je wykorzystywać w sposób maksymalny" (Kwestionariusz wywiadu - Mi- 
chał Wypij, s. 2). Zarazem M. Wypij uważa, że relacje z Rosją winny być kształtowane w sposób możliwie jak najbardziej pragmatyczny.

Postulat złagodzenia - w szerszym lub węższym wymiarze - sankcji wobec Rosji zgłaszają przedstawiciele czterech ugrupowań politycznych. Sojusz Lewicy Demokratycznej stoi na stanowisku, iż na polityce sankcyjnej Polska traci zbyt wiele, co było widoczne choćby w kontekście mistrzostw świata w piłce nożnej, rozgrywanych w Rosji w $2018 \mathrm{r}$. K. Kacprzycki uważa, iż w kwestii ukraińskiej należy poszukać innych, niż sankcje, narzędzi nacisku na Rosję. Reprezentująca PSL poseł U. Pasławska podkreśla konieczność zniesienia sankcji gospodarczych, przy jednoczesnym utrzymaniu sankcji politycznych, zwracając uwagę na istotne straty rolnictwa w województwie warmińsko-mazurskim. Przedstawiciel partii Wolność postuluje ograniczenie sankcji, szczególnie gospodarczych, zauważając że nie zaszkodziły one znacząco rozwojowi gospodarczemu województwa. Z kolei przedstawiciel partii Zmiana opowiada się za zniesieniem - nawet jednostronnym - sankcji wobec Rosji, podkreślając, iż polski przemysł i rolnictwo tracą zbyt wiele na dotychczasowej polityce handlowej Unii Europejskiej, skłaniając jednocześnie Rosję do pogłębienia relacji handlowych z Chinami.

\section{Relacje polsko-rosyjskie w wymiarze regionalnym i lokalnym}

Kolejnym zagadnieniem ujętym w badaniu były relacje polsko-rosyjskie na poziomie regionalnym i lokalnym. W pierwszej kolejności poddano ocenie stosunek mieszkańców województwa warmińsko-mazurskiego do Rosjan, idei współpracy transgranicznej i występowania antyrosyjskości, jak również implikacji z tego wynikających dla programów partyjnych. Większość respondentów ocenia, iż stosunek mieszkańców regionu do Rosjan i idei współpracy transgranicznej jest pozytywny, przy czym dostrzega się pewne różnice poglądów przedstawicieli poszczególnych partii. Przedstawiciel Kukiz'15 podkreśla, że na poziomie międzyludzkim relacje polsko-rosyjskie są wzorowe, co stanowi istotną przesłankę poprawy relacji politycznych w przyszłości. Podobnie uważa przedstawiciel PO, który z kolei podkreśla pragmatyzm mieszkańców województwa oraz to, że pogorszenie stosunków politycznych praktycznie nie wpływa na kontakty międzyludzkie czy też kontakty kulturalne i naukowe. Poseł M. Pampuch (Nowoczesna) uwypukla potencjał współpracy samorządów po obu stronach granicy: „Biorąc pod uwagę m.in. nastawienie samo- 
rządów i mieszkańców do różnych inicjatyw współpracy, m.in. Programu Współpracy Transgranicznej Polska-Rosja, to wszystko wskazuje na to, że mamy pozytywne nastawienie do kwestii kontaktów z Rosjanami i tych kontaktów nie utożsamiamy z reżimem Putina, a raczej odnosimy się do kontaktów międzyludzkich" (Kwestionariusz wywiadu - Mirosław Pampuch, s. 2). Z kolei przedstawiciel Porozumienia docenia zdrowy pragmatyzm w relacjach transgranicznych, w tym w kontaktach społecznych. Przedstawiciel partii Wolność diagnozuje, iż głównym czynnikiem wpływającym na dobre relacje społeczne jest wspólny interes gospodarczy, który dostrzegają mieszkańcy po obu stronach granicy.

Wątki pesymistyczne można dostrzec z kolei w wypowiedziach przedstawicieli PSL i SLD. Poseł U. Pasławska dostrzega dobre relacje międzyludzkie, mimo trudnej historii obu narodów. Z kolei K. Kacprzycki diagnozuje, iż istnieje wyraźny dysonans pomiędzy polsko-rosyjskimi stosunkami transgranicznymi na poziomie społecznym i politycznym. Największy pesymizm wyraża przedstawiciel Zmiany, który jednoznacznie stwierdza, iż poziom rusofobii w polskim społeczeństwie wzrósł w ostatnich latach i może to wpływać również na relacje polsko-rosyjskie na obszarach przygranicznych.

Większość respondentów wyraża pogląd, zgodnie z którym problematyka współpracy transgranicznej z Rosją nie będzie stanowiła głównego temat sporu politycznego w trakcie kampanii przed wyrobami samorządowymi, choć będzie się w niej pojawiała. Przedstawiciel SLD podkreśla, iż ważnym zagadnieniem jest tu nie tylko kwestia zawieszenia małego ruchu granicznego, ale i spory pojawiające się w kontekście polityki historycznej w Polsce (pomnik gen. Iwana Czerniachowskiego w Pieniężnie czy problem pomnika Xawerego Dunikowskiego w Olsztynie). Poseł Pampuch (Nowoczesna) zauważa natomiast, że barierą ograniczającą handel transgraniczny w województwie warmińsko-mazurskim jest nie tylko zawieszenie małego ruchu granicznego, ale i ograniczenie handlu w niedzielę, co w konsekwencji ogranicza przychody sektora handlowego, generowane przez klientów z obwodu kaliningradzkiego. B. Grucela (Razem) twierdzi z kolei, iż „Z pewnością kwestia małego ruchu granicznego będzie poruszana w trakcie kampanii. Myślę, że samorządowcy i mieszkańcy regionu nie zapomną tego Prawu i Sprawiedliwości, że MRG został jednostronnie zawieszony i ta kwestia będzie często poruszana" (Kwestionariusz wywiadu - Bartosz Grucela, s. 3). Zdaniem poseł Pasławskiej (PSL) znaczącą treścią polsko-rosyjskiej współpracy transgranicznej jest również kwestia wdrożenia Programu Współpracy 
Transgranicznej Polska-Rosja 2014-2020 i może stać się to przedmiotem kampanii wyborczej.

Respondenci zauważają również, że współpraca transgraniczna z Rosją i relacje polsko-rosyjskie są w umiarkowanym stopniu przedmiotem dyskursu publicznego, prowadzonego $\mathrm{w}$ regionalnych mediach, przez miejscowych polityków czy społeczność województwa warmińsko-mazurskiego. Przedstawiciel PO podkreśla, że współpraca transgraniczna zdecydowanie bardziej dotyczy społeczności zamieszkującej północną, przygraniczną część województwa. Przedstawiciel SLD wyodrębnia z kolei główne zagadnienia, związane z relacjami polsko-rosyjskimi, które są elementem dyskursu publicznego: współpraca transgraniczna, relacje handlowe oraz uwarunkowania historyczne. Przedstawiciel Nowoczesnej zaznacza, że w ostatnich miesiącach najwięcej dyskutowało się w regionie o zawieszeniu MRG i ewentualnych korzyściach wynikających z mistrzostw świata w piłce nożnej. Krytycznie o dyskursie prowadzonym w regionie, odnoszącym się do relacji z Rosją, wypowiadają się natomiast przedstawiciele partii Wolność oraz Zmiana. Przedstawiciel Wolności podkreśla, że relacje z Rosją i ich miejsce w dyskursie publicznym często zależy od bieżącej polityki. Z kolei przedstawiciel Zmiany uważa, iż zbyt często Rosja jest przedstawiana w polskich mediach w sposób prześmiewczy, zaś rozwijanie relacji polsko-rosyjskich jest komentowane w sposób krytyczny.

\section{Prognoza rozwoju relacji polsko-rosyjskich i plany partii politycznych}

Trzecim blokiem tematycznym uwzględnionym w badaniu była prognoza rozwoju relacji polsko-rosyjskich oraz plany partii politycznych z tym związane. W pierwszej kolejności dokonano oceny potencjału na powstanie w województwie warmińsko-mazurskim ugrupowania lub ruchu społecznego, opowiadającego się otwarcie za poprawą relacji polsko-rosyjskich. Programy partii w tym obszarze można podzielić na trzy grupy. Do pierwszej zaliczyć należy te ugrupowania, których przedstawiciele odnoszą się sceptycznie do potencjału powstania w regionie ruchu społecznego czy politycznego o wskazanym profilu. Przedstawiciel partii Wolność deklaruje, iż w jego opinii nie tylko nie ma takiego potencjału, ale że społeczeństwu te kwestie są raczej obojętne. Podobnie deklaruje przedstawiciel Nowoczesnej. 
Druga grupa to ugrupowania, których przedstawiciele nie widzą potencjału powstania takiego ruchu społecznego, choć dostrzegają pewne obszary współpracy społeczności lokalnych, w których można znaleźć swoisty potencjał pragmatyzacji relacji z Rosją. Taką optykę prezentuje przedstawiciel PO, który stwierdza, iż nie ma szans na powstanie takiego ruchu ze względu na fakt, iż to nie regiony kreują współpracę transgraniczną; zarazem dostrzega szanse współpracy społecznej. Przedstawiciel SLD potwierdza natomiast istnienie potencjału do rozwoju relacji transgranicznych, co w jego ocenie niekoniecznie przekłada się na możliwość politycznego wykorzystania tej współpracy. Zdaniem przedstawiciela partii Porozumienie, niezależnie od relacji międzypaństwowych w regionie przygranicznym, ,,po polskiej i po rosyjskiej stronie granicy idea poprawy relacji będzie się rozwijać w oparciu o gospodarkę i ewentualnie wymianę kulturalną" (Kwestionariusz wywiadu - Michał Wypij, s. 3). Nie powinno to przełożyć się natomiast na poziom relacji międzypaństwowych. Przedstawicielka PSL zauważa, że nie ma takiego potencjału na poziomie krajowym. W odniesieniu do współpracy społecznej, szczególnie na obszarach przygranicznych, silna jest idea współpracy transgranicznej z obwodem kaliningradzkim, co nie powinno przełożyć się jednak na potencjał polityczny takiego ruchu. Przedstawicielka PiS zauważa z kolei, iż „taki potencjał z pewnością istnieje w grupie przedsiębiorców prowadzących interesy z Rosją, ponieważ znają Rosję i mają kontakty z Rosjanami. Nie wiem czy taki ruch odniósłby sukces i zostałby zauważony przez resztę społeczeństwa, ponieważ to zależy od wielu czynników" (Kwestionariusz wywiadu - Iwona Arent, s. 4).

Trzecia grupa ugrupowań to partie, których przedstawiciele dostrzegają potencjał powstania ugrupowania lub ruchu społecznego postulującego pogłębienie relacji polsko-rosyjskich. Poseł A. Maciejewski (Kukiz’15) stwierdza m.in.: „Ja taki potencjał widzę, tyle że nie po to, by samodzielnie prowadzić relacje polsko-rosyjskie, lecz by rozwijać współpracę transgraniczną. Jest możliwa taka płaszczyzna współpracy, tylko nie ma koordynacji i nie ma jednego miejsca prowadzenia takich działań. Optuję za tym, by skoordynować to i oddać w jedne ręce" (Kwestionariusz wywiadu - Andrzej Maciejewski, s. 4). Bardziej jednoznaczny jest natomiast przedstawiciel partii Zmiana, który dostrzega polityczny potencjał takiego ugrupowania: „Wszelkie badania opinii publicznej wykazują, że w polskim społeczeństwie około 10-15\% populacji opowiada się za racjonalnym i pragmatycznym ułożeniem relacji z Rosją. Szczególny potencjał dostrzegałbym w rozwoju współpracy gospodarczej z Rosją, 
która mogłaby stanowić podstawę do polepszenia relacji politycznych" (Kwestionariusz wywiadu - Tomasz Jankowski, s. 4). Respondent zauważa jednocześnie, iż jest to szczególnie ważne w kontekście przygranicznego położenia województwa warmińsko-mazurskiego.

Kolejnym istotnym zagadnieniem uwzględnionym w badaniu była kwestia zgodności - w odniesieniu do relacji polsko-rosyjskich - programów politycznych partii, tworzonych na poziomie centralnym z poglądami przedstawicieli tych partii w województwie warmińsko-mazurskim. Skonfrontowano opinie respondentów dotyczące dylematu: na ile program i działania partii (na szczeblu krajowym) są zbieżne z ocenami działaczy regionalnych? Wszyscy uczestnicy badania podkreślają, iż w ich partiach problem dysonansu pomiędzy programami partii a poglądami działaczy z Warmii i Mazur nie istnieje. Przedstawiciel partii Wolność zaznacza, iż brak różnic w poglądach centrali partyjnej i działaczy z regionu wynika z faktu, że partia kieruje się wolnością gospodarczą, a nie polityką. Przedstawiciel partii Razem podkreśla, iż to właśnie oddział warmińsko-mazurski w znacznej mierze kreował program tego ugrupowania w odniesieniu do szeroko pojętej polityki wschodniej, w tym relacji z Rosją. K. Kacprzycki z SLD zaznacza: „Zarówno nasi politycy na szczeblu centralnym, jak i tu, w regionie mówią o konieczności poprawy relacji z Rosją, przy założeniu konieczności egzekwowania odpowiedzialności Rosji za jej działania na arenie międzynarodowej” (Kwestionariusz wywiadu - Krzysztof Kacprzycki, s. 3). Zarówno przedstawiciele PO, jak i Nowoczesnej, PiS czy Porozumienia zaznaczają, iż ich programy są spójne z pragmatyką działania w odniesieniu do relacji z Rosją.

Wśród postulatów, które - w kontekście relacji z Rosją - zamierzają realizować poszczególne partie w przyszłości, w wypowiedziach respondentów pojawiają się w szczególności trzy kwestie: 1) ogólny rozwój współpracy transgranicznej z Rosją, 2) przywrócenie małego ruchu granicznego i 3) rozwój relacji handlowych. Postulat ułatwień handlowych oraz przywrócenie MRG jest uwypuklane w sposób szczególny przez przedstawicieli partii Wolność oraz PSL. Z kolei przedstawiciele PO i Nowoczesnej podkreślają, iż - poza przywróceniem małego ruchu granicznego - zasadniczym postulatem powinno być umiejscowienie naszej polityki wobec Rosji w kontekście polityki Unii Europejskiej. Zasadniczym postulatem partii Zmiana jest natomiast umożliwienie normalnej działalności ugrupowania (uwolnienie lidera partii, M. Piskorskiego i rejestracja ugrupowania) oraz „odkłamywanie” antyrosyjskiej propagandy, obecnej w polskim dyskursie publicznym. Przedstawicielka PiS podkre- 
śla, iż jej ugrupowanie będzie gotowe na poprawę relacji z Rosją o ile ta wycofa się z aktywności na Ukrainie i powróci do przestrzegania prawa międzynarodowego.

Ostatnim zagadnieniem poruszonym w badaniu była rola problematyki rosyjskiej w kształtowaniu sceny politycznej województwa warmińsko-mazurskiego. Zapytano respondentów czy relacje z Rosją mogą tworzyć osie sporu politycznego w regionie oraz o szanse w wyborach samorządowych ugrupowań, opowiadających się za poprawą relacji z Rosją. Twierdząco na tak postawione pytania - przynajmniej jeśli chodzi o regionalną scenę polityczną - odpowiedzieli przedstawiciele partii Razem, Platformy Obywatelskiej, Sojuszu Lewicy Demokratycznej i Nowoczesnej. Zarazem podkreślili oni, iż jest to jeden z wielu czynników ewentualnego sukcesu wyborczego i to głównie w wyborach do sejmiku województwa warmińsko-mazurskiego. W opinii J. Protasa (PO) „Jest to bardziej skomplikowany problem. Zależy jak rozumiemy polepszenie relacji z Rosją, co jest przecież uwarunkowane całym szeregiem czynników. Można powiedzieć: nic na siłę. $Z$ pewnością należy starać się budować dobre relacje z sąsiadami, ale nie za wszelką cenę. Czym innym jest polityka wobec imperialnie nastawionej Rosji, a czym innym współpraca transgraniczna z obwodem kaliningradzkim" (Kwestionariusz wywiadu - Jacek Protas, s. 5).

Przedstawiciel Kukiz'15 zauważa, iż w kwestii relacji polsko-rosyjskich „mamy do czynienia nie z dyskusją, ale z cynicznym wykorzystywaniem mieszkańców i samorządów regionu przez wszystkie siły polityczne" (Kwestionariusz wywiadu - Andrzej Maciejewski, s. 5). Z kolei przedstawiciel partii Zmiana podkreśla, iż mogłoby to stanowić oś podziału politycznego, gdyby społeczeństwo miało świadomość strat wynikających z pogorszenia się relacji polsko-rosyjskich. T. Jankowski zauważa, iż paradoksalnie antyrosyjskie działania rządu Prawa i Sprawiedliwości tworzą dobry klimat dla współpracy z Rosją, gdyż pozostałe partie mogą podkreślać swoje pragmatyczne podejście do kształtowania relacji polsko-rosyjskich. Przedstawiciele partii Wolność, Porozumienia, PSL i PiS wyrażają opinię, zgodnie z którą problematyka relacji polsko-rosyjskich i współpracy transgranicznej stanowi zaledwie jeden z wielu tematów sporu politycznego tak na szczeblu krajowym, jak i samorządowym. Respondenci podkreślają, iż samorząd nie prowadzi samodzielnej polityki zagranicznej, dlatego też trudno jest mu zgłaszać określone postulaty w tym zakresie. Poza tym, to nie relacje polsko-rosyjskie determinują szanse rozwojowe województwa warmińsko-mazurskiego i - tym bardziej - gospodarki kraju. 


\section{Podsumowanie}

Przeprowadzone badanie umożliwiło odniesienie się do pytań badawczych, postawionych we wstępie do niniejszego artykułu. Przedstawiciele wszystkich partii politycznych uwzględnionych w wywiadzie dostrzegają znaczenie relacji polsko-rosyjskich tak w programach swoich partii, jak i w życiu politycznym województwa warmińsko-mazurskiego. Analiza jakościowa wykazała, iż deklaracje programowe przedstawicieli partii i ugrupowań politycznych można podzielić na trzy grupy, przedstawione w poniższej tabeli.

Tabela 1

Analiza jakościowa deklaracji przedstawicieli partii i ugrupowań politycznych w województwie warmińsko-mazurskim dotyczących relacji polsko-rosyjskich

\begin{tabular}{||l|l|l||}
\hline $\begin{array}{c}\text { Partia/ugrupo- } \\
\text { wanie }\end{array}$ & Przedstawiciel & \multicolumn{1}{|c|}{ Glówne postulaty } \\
\hline 1 & 2 & \multicolumn{1}{|c|}{3} \\
\hline Kukiz'15 & A. Maciejewski & $\begin{array}{l}\text { Pragmatyzm i uwzględnienie zasady wzajemności } \\
\text { w relacjach z Rosją; zrozumienie dla argumentów } \\
\text { za zawieszeniem małego ruchu granicznego, zwią- } \\
\text { zanych z bezpieczeństwem. }\end{array}$ \\
\hline $\begin{array}{l}\text { Prawo } \\
\text { i Sprawiedliwość }\end{array}$ & I. Arent & $\begin{array}{l}\text { Poprawa relacji z Rosją jest potrzebna i możliwa, } \\
\text { ale jedynie w przypadku szanowania przez Rosję } \\
\text { prawa międzynarodowego; decyzja o zawieszeniu } \\
\text { stosowania MRG była podyktowana kwestiami } \\
\text { bezpieczeństwa i powinna być oceniania z tej per- } \\
\text { spektywy; sankcje wobec Rosji są rezultatem agre- } \\
\text { sywnej polityki Rosji i, tak długo, jak długo się ona } \\
\text { nie zmieni, sankcje powinny być utrzymane. }\end{array}$ \\
\hline Porozumienie & M. Wypij & $\begin{array}{l}\text { Pragmatyzm i uwzględnienie zasady wzajemności } \\
\text { w relacjach z Rosją; zrozumienie wobec zawieszenia } \\
\text { małego ruchu granicznego; utrzymanie sankcji wo- } \\
\text { bec Rosji wynika z lojalności wobec naszych sojusz- } \\
\text { ników z UE; relacje z Rosją winny być kształtowane } \\
\text { w sposób możliwie jak najbardziej pragmatyczny. }\end{array}$ \\
\hline Platforma \\
Obywatelska RP & $\begin{array}{l}\text { Polepszenie współpracy społecznej, przy zachowa- } \\
\text { niu niezmiennego stanu relacji politycznych. }\end{array}$ \\
\hline Bazem & $\begin{array}{l}\text { Relacje z Rosją w szerszym kontekście stosunków } \\
\text { UE-Rosja; postulat wznowienia małego ruchu } \\
\text { granicznego; polityka sankcyjna UE jest jak naj- } \\
\text { bardziej uzasadniona i celowa, zarazem wszędzie } \\
\text { tam, gdzie działania polskie nie burzyłyby wspólnej } \\
\text { polityki UE wobec Rosji - należy ze wschodnim } \\
\text { sąsiadem współpracować. }\end{array}$ \\
\hline Brucela
\end{tabular}




\begin{tabular}{|c|c|c|}
\hline 1 & 2 & 3 \\
\hline $\begin{array}{l}\text { Sojusz Lewicy } \\
\text { Demokratycznej }\end{array}$ & K. Kacprzycki & $\begin{array}{l}\text { Potępienie agresji militarnej, zarazem poszukiwa- } \\
\text { nie obszarów współpracy; na polityce sankcyjnej } \\
\text { Polska traci zbyt wiele; w kwestii ukraińskiej nale- } \\
\text { ży poszukać innych, niż sankcje, narzędzi nacisku } \\
\text { na Rosję. }\end{array}$ \\
\hline Nowoczesna & M. Pampuch & $\begin{array}{l}\text { Relacje z Rosją w szerszym kontekście stosunków } \\
\text { UE-Rosja; postulat wznowienia małego ruchu gra- } \\
\text { nicznego; polityka międzynarodowa Federacji Ro- } \\
\text { syjskiej, jak i szeroko pojęta solidarność europej- } \\
\text { ska - argumentami za utrzymaniem sankcji wobec } \\
\text { Rosji. }\end{array}$ \\
\hline $\begin{array}{l}\text { Polskie } \\
\text { Stronnictwo } \\
\text { Ludowe }\end{array}$ & U. Pasławska & $\begin{array}{l}\text { Postulat wznowienia relacji handlowych z Rosją; } \\
\text { konieczność zniesienia sankcji gospodarczych wo- } \\
\text { bec Rosji, przy jednoczesnym utrzymaniu sankcji } \\
\text { politycznych. }\end{array}$ \\
\hline Wolność & A. Wyrębek & $\begin{array}{l}\text { Polityka zagraniczna sprzyjająca polskim inte- } \\
\text { resom; postulat poprawy relacji gospodarczych, } \\
\text { w tym tych związanych z handlem surowcami; za- } \\
\text { wieszenie małego ruchu granicznego - skandalem; } \\
\text { ograniczenie sankcji, szczególnie gospodarczych, } \\
\text { zauważając że nie zaszkodziły one znacząco roz- } \\
\text { wojowi gospodarczemu województwa. }\end{array}$ \\
\hline Zmiana & T. Jankowski & $\begin{array}{l}\text { Zrównoważenie relacji z Rosją i Zachodem; brak } \\
\text { zagrożenia politycznego i militarnego ze strony Ro- } \\
\text { sji; postulat wystąpienia Polski z NATO; postulat } \\
\text { zniesienia sankcji wobec Rosji - polski przemysł } \\
\text { i rolnictwo tracą zbyt wiele na dotychczasowej po- } \\
\text { lityce handlowej Unii Europejskiej. }\end{array}$ \\
\hline
\end{tabular}

Źródło: Opracowanie własne na podstawie wyników wywiadów.

Do pierwszej grupy należy zaliczyć partię Kukiz'15, Prawo i Sprawiedliwość oraz w pewnym zakresie Porozumienie. Przedstawiciele tych ugrupowań postulują pragmatyczną, choć asertywną politykę wobec Rosji, nastawioną na realizację polskich interesów. Zarazem, relacje dwustronne z Rosją powinny być funkcją przestrzegania przez Rosję prawa międzynarodowego, nawet gdyby miało to odbywać się kosztem pogorszenia relacji. Druga grupa partii, do której należy zaliczyć Razem, Platformę Obywatelską, Sojusz Lewicy Demokratycznej oraz Nowoczesną to ugrupowania, których przedstawiciele deklarują przywiązywanie dużej wagi do relacji z Rosją, przy czym poszczególne elementy owych relacji powinny ulec rozdzieleniu na poziom międzypaństwowy i transgraniczny. Trzecia grupa ugrupowań to partie, których przedstawiciele 
wskazują konkretne obszary, w których owe relacje powinny ulec polepszeniu. Partia Wolność i Polskie Stronnictwo Ludowe postulują poprawę relacji handlowych i niewiązanie ich z relacjami politycznymi. Z kolei przedstawiciel partii Zmiana deklaruje nie tylko konieczność poprawy relacji handlowych, ale i wystąpienie Polski z NATO, co miałoby polepszyć również relacje polityczne $\mathrm{z}$ Rosją.

Większość respondentów ocenia, iż stosunek mieszkańców regionu do Rosjan i idei współpracy transgranicznej jest pozytywny. Respondenci zauważają również, że kwestia współpracy transgranicznej z Rosją i relacje polsko-rosyjskie są w umiarkowanym stopniu przedmiotem dyskursu publicznego, prowadzonego $\mathrm{w}$ regionalnych mediach, przez regionalnych polityków czy społeczność województwa warmińsko-mazurskiego.

Reprezentanci badanych ugrupowań dostrzegają wagę relacji polsko-rosyjskich, choć dość sceptycznie wyrażają się na temat możliwości wykorzystania tego zagadnienia do kształtowania regionalnej sceny politycznej w przyszłości. Przeważający jest pogląd, zgodnie z którym brak jest realnych przesłanek do powstania ruchu politycznego czy społecznego opowiadającego się za poprawą relacji z Rosją, choć istnieją pewne obszary współpracy, które dla społeczności województwa warmińsko-mazurskiego mogą być ,atrakcyjne” politycznie, i w których można znaleźć swoisty potencjał pragmatyzacji relacji z Rosją. Przedstawiciele partii proponują realizację szeregu postulatów, wśród których znalazły się: ogólny rozwój współpracy transgranicznej z Rosją, przywrócenie małego ruchu granicznego oraz rozwój relacji handlowych. Zarazem większość przedstawicieli partii politycznych uważa, że relacje z Rosją mogą jedynie w bardzo ograniczonym stopniu tworzyć osie sporu politycznego w regionie. Sceptycznie wypowiadano się również o szansach w wyborach samorządowych ugrupowań opowiadających się za poprawą relacji z Rosją.

Istotnym zagadnieniem badawczym jest również porównanie deklaracji przedstawicieli partii politycznych, którzy wzięli udział w badaniu z zapisami programów ugrupowań, które reprezentują. Materiałem porównawczym były tu dokumenty programowe partii, które zostały poddane analizie przez autora $\mathrm{w}$ ramach badań przygotowawczych do niniejszej publikacji ${ }^{10}$.

Biorąc pod uwagę zapisy programów wyborczych, zarówno Platforma Obywatelska, jak i Nowoczesna deklarują krytyczne stanowisko wobec działań Rosji na arenie międzynarodowej. W programie wyborczym PO,

${ }^{10}$ Zob. Żęgota, 2018b, s. 157-183. 
przygotowanym na wybory w 2015 r. wyrażono krytyczny stosunek wobec polityki zagranicznej Rosji, zarzucając wykorzystanie przewagi militarnej oraz surowcowego charakteru gospodarki. Podkreślono europejski kontekst polityki wobec Rosji (Polska przyszłości, 2015, s. 65). Krytyczne stanowisko wobec polityki międzynarodowej Rosji wyrażała również Nowoczesna, w której programie politycznym stwierdzono, iż „realnym zagrożeniem w regionie jest dziś przede wszystkim nieprzewidywalna i agresywna postawa Rosji” (Nowoczesna Polska, 2016, s. 105). Zarazem, deklaracje przedstawicieli partii uwzględnione w badaniu są bardziej zniuansowane: postulują oni konieczność utrzymania sankcji wobec Rosji, przy jednoczesnym rozwijaniu współpracy transgranicznej. Istotnym spostrzeżeniem jest również to, iż zarówno w badaniu kwestionariuszowym, jak i w zapisach programów politycznych obu partii postuluje się „osadzenie” polityki polskiej wobec Rosji w polityce Unii Europejskiej i NATO.

Więcej podobieństw $\mathrm{w}$ deklaracjach przedstawicieli partii i programów politycznych dostrzeżono w odniesieniu do Prawa i Sprawiedliwości. W dokumentach programowych PiS z 2014 i 2015 r. stwierdzono, iż istnieją wyraźne przeciwwskazania współpracy z Rosją, głównie wobec niespełniania przez to państwo elementarnych zasad prawa międzynarodowego (Zdrowie, s. 42). Zaznaczono, iż w przypadku kontynuowania wspierania przez Rosję separatystów na wschodzie Ukrainy należy konsekwentnie wspierać władze w Kijowie (Dworczyk, 2015, s. 85). Podobną postawę w relacjach z Rosją postuluje przedstawicielka PiS, która wzięła udział w badaniu, deklarując jednoznacznie, że polepszenie relacji z Federacją Rosyjską, w tym również na poziomie współpracy transgranicznej, jest możliwe tylko w przypadku przestrzegania przez Rosję prawa międzynarodowego i dobrosąsiedzkich stosunków.

Pewne różnice między dokumentami programowymi a deklaracjami można dostrzec w programie Polskiego Stronnictwa Ludowego. W programie ugrupowania postulowano rozwijanie pozytywnych relacji ze wszystkimi sąsiadami, w tym zarówno z Rosją, jak i Ukrainą. Partia opowiada się za przywróceniem pokoju na Ukrainie i polepszeniem relacji rosyjsko-ukraińskich (Blisko, 2015, s. 31). Co godne podkreślenia, w programie politycznym PSL brak jest tak wyraźnej artykulacji postulatu odstąpienia od sankcji gospodarczych wobec Rosji i przywrócenia relacji handlowych, jak to ma miejsce w deklaracjach przedstawicielki ugrupowania zawartych w wywiadzie. Zarazem poseł U. Pasławska podkreśla, że relacje transgraniczne - które powinny ulec poprawie - zawsze są funkcją stosunków politycznych na poziomie centralnym. 
Warte odnotowania jest również stanowisko partii Zmiana, która zarówno w programie, jak i deklaracjach przedstawiciela ugrupowania wyraża konieczność znaczącej poprawy relacji gospodarczych i politycznych z Rosją. T. Jankowski deklaruje m.in., iż jego ugrupowanie „postuluje wystąpienie Polski z NATO i ogłoszenie neutralności. Opowiadamy się zarazem za pozostaniem w Unii Europejskiej przy jednoczesnym wykorzystywaniu wielowektorowości naszej polityki zagranicznej” (Kwestionariusz wywiadu - Tomasz Jankowski, s. 1). Ten sam postulat, wyrażany w podobnych słowach, znajduje się w programie partii przygotowanym w 2015 r. (Zmiana, 2016, s. 14-16). Wskazuje to na największą spójność deklaracji przedstawiciela partii z jej dokumentami programowymi.

\section{Bibliografia}

Antoszewski A., Herbut R. (2004), Leksykon politologii, Wydawnictwo Atla 2, Wrocław. Aresztowany prokremlowski polityk rejestruje partię. Prokuratura stara się to zablokować, https://www.tvn24.pl/wiadomosci-z-kraju,3/zmiana-aresztowanyprokremlowski-polityk-rejestruje-partie,675455.html, 14.01.2019.

Bäcker R. i in. (2016), Metodologia badań politologicznych, Polskie Towarzystwo Nauk Politycznych, Warszawa.

Blisko ludzkich spraw (2015), Deklaracja wyborcza PSL.

Budge I. (1994), A new spatial theory of party competition, „British Journal of Political Science", vol. 24 (4).

Budge I., Klingemann H. D., Volkens A., Bara J., McDonald M. (2006), Mapping Policy Preferences: Estimates for Parties, Electors, and Governments in Eastern Europe, European Union and OECD 1990-2003, Oxford University Press, Oxford.

Chodubski A. (2004), Wstęp do badań politologicznych, Wydawnictwo Uniwersytetu Gdańskiego, Gdańsk.

Dworczyk M. (2015), Polska polityka wschodnia, w: Myślac Polska, Konwencja Programowa Prawa i Sprawiedliwości oraz Zjednoczonej Prawicy, Katowice, 3-5 lipca $2015 \mathrm{r}$.

Indraszczyk A. (2008), Problem bezpieczeństwa państwowego i międzynarodowego w programach polskich partii politycznych, „Doctrina. Studia Społeczno-Polityczne", nr 5.

Kitschelt H. (1999), Post-communist party systems: competition, representation and inter-party cooperation, University Press, Cambridge.

Koronowski M. (2018), Krzysztof Kacprzycki oficjalnie żegna się z SLD, http://olsztyn.wyborcza.pl/olsztyn/7,48726,24137219,krzysztof-kacprzycki-oficjalniezegna-sie-z-sld.html, 18.01.2019. 
Kwestionariusz wywiadu - Andrzej Maciejewski, Kuiz'15.

Kwestionariusz wywiadu - Andrzej Wyrębek, Wolność.

Kwestionariusz wywiadu - Bartosz Grucela, Razem.

Kwestionariusz wywiadu - Iwona Arent, Prawo i Sprawiedliwość.

Kwestionariusz wywiadu - Jacek Protas, Platforma Obywatelska RP.

Kwestionariusz wywiadu - Krzysztof Kacprzycki, Sojusz Lewicy Demokratycznej.

Kwestionariusz wywiadu - Michał Wypij, Porozumienie.

Kwestionariusz wywiadu - Mirosław Pampuch, Nowoczesna.

Kwestionariusz wywiadu - Tomasz Jankowski, Zmiana.

Kwestionariusz wywiadu - Urszula Pasławska, Polskie Stronnictwo Ludowe.

Mair P. (2017), Rząd reprezentatywny vs rzad odpowiedzialny, w: Oblicza demokracji. Partie i systemy partyjne w ujęciu Petera Maira, red. W. Gagatek, K. Walecka, Ośrodek Myśli Politycznej, Kraków.

Nowoczesna Polska dla każdego (2016), https://nowoczesna.org/program/, 19.01.2019.

Polska przyszłości (2015), Program Platformy Obywatelskiej RP, Warszawa.

Raciborski J. (2003), Wybory i wyborcy, w: Demokratyzacja polska 1989-2003, red. J. Wiatr, J. Raciborski, J. Bartkowski, B. Frątczak-Rudnicka, J. Kilian, Scholar, Warszawa.

Rapley T. (2010), Analiza konwersacji, dyskursu i dokumentów, PWN, Warszawa.

Rosińska-Bukowska M. (2015), Handel rolno-spożywczy UE-Rosja - efekty rosyjskich sankcji, „Zeszyty Naukowe Szkoły Głównej Gospodarstwa Wiejskiego w Warszawie", t. 15 (XXX), z. 1.

Tyrała M. (2018), Wpływ postulatów programowych na sukces wyborczy - na przykładzie partii: PiS, PO, ZL w wyborach parlamentarnych $w$ Polsce $w 2015$ roku, „Środkowoeuropejskie Studia Polityczne”, nr 1.

Woźniak W. (2017), Programy polskich partii politycznych jako materiał empiryczny w badaniach dyskursu politycznego, „Środkowoeuropejskie Studia Polityczne", $\mathrm{nr} 2$.

Wykaz partii wpisanych do ewidencji partii politycznych (na podstawie prawomocnych postanowień w sprawach o wpis do ewidencji przekazanych Państwowej Komisji Wyborczej przez Sąd Okręgowy w Warszawie w trybie określonym art. 15 ustawy o partiach politycznych), http://pkw.gov.pl/322_Wykaz_partii_politycznych, 22.11.2018.

Zawadzka K. (2016), Związi partnerskie mniejszości seksualnych w programach polskich partii politycznych, „Acta Politica Polonica”, nr 1 (35).

Zdrowie, Praca, Rodzina (2014), Program Prawa i Sprawiedliwości, Warszawa.

Zmiana. Praca - Pokój - Patriotyzm. Program polityczny (2016), Warszawa.

Żęgota K. (2018a), Mały ruch graniczny w kontekście zmieniających się uwarunkowań relacji polsko-rosyjskich, w: Mały ruch graniczny w warunkach kryzysu w relacjach polsko-rosyjskich, red. A. Żukowski, M. Chełminiak, W. Koto- 
wicz, K. Żęgota, Instytut Nauk Politycznych, Uniwersytet Warmińsko-Mazurski w Olsztynie, Olsztyn.

Żęgota K. (2018b), Relacje z Federacją Rosyjska w programach wybranych polskich ugrupowań politycznych - zarys analizy ilościowej i jakościowej, „Myśl Ekonomiczna i Polityczna", nr 4(63).

\title{
Polish-Russian cross-border cooperation and Polish-Russian relations in the platforms of selected political parties and declarations of their representatives in the Warmia-Mazury Region. Outline of analysis of field research results
}

\begin{abstract}
Summary
The objective of the article is a qualitative analysis of the results of interviews conducted with representatives of political parties from the Warmia-Mazury Region as concerns Polish-Russian cross-border cooperation and Polish-Russian relations in the platforms of political parties. The study demonstrated that the representatives of all political parties interviewed acknowledge the importance of Polish-Russian relations, both in their party platforms and in the political life of the Warmia-Mazury Region. Party representatives emphasize the importance of Polish-Russian cross-border cooperation for the functioning of the regional political scene. Most respondents believe that inhabitants of the region have a positive attitude to Russia and the idea of cross-border cooperation.
\end{abstract}

Key words: Polish-Russian cross-border cooperation, Polish-Russian relations, political parties, party platforms 